\title{
Trevor Noah and the contingent politics of racial joking
}

\author{
Jennalee Donian \\ University of Fort Hare, South Africa \\ donian.jennalee@gmail.com
}

\author{
Nicholas Holm \\ Massey University, New Zealand \\ N.H.F.Holm@massey.ac.za
}

\begin{abstract}
This article takes up the transnational comedy career of Trevor Noah as a way to explore how the political work of racial comedy can manifest, circulate and indeed communicate differently across different racial-political contexts. Through the close textual analysis of two key comic performances - "The Daywalker" (2009) and "Son of Patricia” (2018), produced and (initially) circulated in South Africa and the USA, respectively - this article explores the extent to which Noah's comic treatment of race has shifted between the two contexts. In particular, attention is paid to how Noah incites, navigates and mitigates potential sources of offence surrounding racial anxieties in the two contexts, and how he evokes his own "mixed-race" status in order to open up spaces of permission that allow him to joke about otherwise taboo subjects. Rejecting the claim that the politics of Noah's comedy is emancipatory or progressive in any straightforward way, by means of formal analyses we argue that his comic treatment of race does not enact any singular politics, but rather that the political work of his racial humour shifts relative to its wider political contexts. Thus, rather than drawing a clear line between light entertainment and politically meaningful humour, this article argues that the political valence of racial joking can be understood as contingent upon wider discourses of race that circulate in national-cultural contexts.
\end{abstract}

Keywords: comedy, race, racism, politics, Trevor Noah

\section{Introduction}

The political role of race has long been a central aspect of the stand-up comedy of Trevor Noah. Acclaimed in his native South Africa for his comic negotiation of the fraught racial terrain of the post-apartheid era, the comedian ascended to the ranks of global comedy royalty in 2015 when he was anointed successor to Jon Stewart on America's highly rated and globally 
circulated The Daily Show. Although Noah had been a global touring comedian of note prior to this appointment, his new position provided a nearly unrivalled platform for sharing his particular take of racially charged political humour with an international audience. However, this change of context not only increased the potential reach of Noah's comedy, it also situated it within the new and differently complex constellation of predominantly US-centric racial politics. While race is central to the political structures of both South Africa and the United States of America, the accordant tensions, anxieties and structures of prejudice around the topic manifest in markedly distinctive ways in the two contexts as a result of their divergent histories of race relations (Fredrickson 1997; Goldberg 2002).

Indeed, the legacy of legal racial segregation in both South Africa (under apartheid) and the United States (Jim Crow Laws) has ensured that perennial concerns with race, in one form or another, remain endemic, permanent and central features of social life in both countries. In South Africa, black people are the overwhelming majority and hold political power, whereas they constitute a relatively small minority in America and are still fighting to be considered completely equal to their white counterparts. This is especially evident in terms of the restrictive voter identification laws, which disenfranchise minority voters (among them AfricanAmericans) from electorates (Cohen 2016: 45-46). In South Africa, attempts are being made politically, economically and socially to "redress" historic injustices, yet the enforced segregation of that past has fostered cross cultural ignorance and prejudice, and incited "intercultural" misunderstanding and conflict (Franchi 2003: 161). At the same time, the racialised parameters imposed during apartheid are no longer so explicit, and has resulted in a more nuanced fluidity of racialised identity. Subsequently, many individuals and groups are being forced to negotiate new identities in a rapidly shifting socio-cultural context (Stevens \& Lockhat 1997; Gillborn 2005; Sonn 2006; Rabaka 2007). Contrarily, a rigid black/white binary paradigm characterises race discourse in the US (whereby other groups are either assimilated into blacks or whites or silenced altogether; see Perea 1997: 1219-1220), as is evident by the recent spate of police brutality attacks against blacks, leading to the "Black Lives Matter" movement. Despite many contemporary socio-political issues in both South Africa and the US being shaped by race, Americans (in particular the white population) seem to shy away from public discussions of such matters (Sue 2015: 134), or take a political stance of avoidance (Trawalter \& Richeson 2008), while South African society seems to be more willing to admit the existence of race and racism. In this article, we take up Noah's transnational comedy career as a way to explore how the political work of racial comedy can manifest and function differently across different racial-political contexts.

This article is concerned with how two key comic performances - "The Daywalker" (2009) and "Son of Patricia" (2018) - can help trace how the comic treatment of race manifests, circulates and indeed communicates differently in different contexts. These examples have been chosen because they are indicative of the two key phases of Noah's comedy career. "The Daywalker" was Noah's first one-man show and is representative of the South African phase of his comedy, where he was almost exclusively addressing himself to local audiences. In contrast, "Son of Patricia" is emblematic of Noah's later status as a globally recognised comedian who is addressing himself to not only American audiences, but also the global audience enabled by the Netflix distribution platform.

Taking our lead from literary and media studies approaches to the study of humour (Palmer 1987; Lewis 1989; Lockyer \& Pickering 2009; Davis 2014), we approach these two representative examples by way of long-form interpretive analysis that takes into account the textual, performative and mediated aspects of the examples as a way of accounting for wider social and political ramifications of comedy. These analyses are also closely informed by critical and cultural theory as a means to model and explicate the wider political function of comic cultural texts (Holm 2017; Donian 2019). In particular, we draw upon work done under the 
banner of critical race theory as a means to articulate the ways in which racial politics are entangled with Noah's humour. Thus, through close textual analyses of these stand-up performances, we explore how Noah's comic treatment of race shifts between the local South African and more globally orientated American contexts. Central to these analyses is a concern with how Noah's humour functions to make race a laughing matter, and how his comic handling of race shifts within the context of different racial-political regimes. In particular, attention is paid to how Noah incites, navigates and mitigates potential sources of offence surrounding racial anxieties in the two contexts, and how he evokes his own "mixed-race" status in order to open up spaces of permission that allow him to joke about otherwise taboo subjects. However, in contrast to previous claims that Noah's "comedic discourses play a vital role in the struggle against hegemonic racism" (Rossing 2016: 614), through this formal analytic work we argue that his comic treatment of race does not enact a singular and stable politics, but rather that the political work of his racial humour shifts relative to its wider political contexts. Thus, rather than drawing a clear line between "mere amusement" and politically meaningful humour, we argue that the political valence of Noah's racial joking needs to be understood as contingent upon wider discourses of race that circulate in national-cultural contexts.

\section{The life and comic times of Trevor Noah}

Trevor Noah was born on 20 February 1984 in Johannesburg, South Africa, to a black Xhosa mother and a white Swiss-German father at the height of the apartheid regime. At the time, his parents' union was illegal, leading Noah to often refer to the fact that he was "born a crime" (also the title of his best-selling autobiographical book; see also Nwadigwe 2018). Consequently, his mother was jailed and fined one year after his birth, he had very little contact with his father, and he could not be seen in public alongside either of his parents (Bahr 2016; Noah 2016a: 25). Noah was raised primarily by his mother alongside his grandmother in the slums of Soweto: a poor black segregated urban settlement outside the city of Johannesburg which was at the epicentre of political protest during apartheid (Noah 2016a: 25). As a lightskinned child in a black designated area, Noah spent most of his early childhood in hiding from the authorities who would often deport, arrest or even incarcerate anyone who did not comply with the racially partitioned system of development enforced under the Group Areas Act (Noah 2016a: 26). Growing up "mixed-race" under a system which officially sponsored racial categorisation and segregation, Noah often relied on language as a tool to bridge the race gap and "cross boundaries, handle situations, [and] navigate the world" (Noah 2016a: 42). Fluent in a mélange of languages, including English, Afrikaans and German (to a degree), as well as four native African languages - Sotho, Zulu, Tsonga and Xhosa (McCarthy 2017) - Noah became a self-declared "cultural chameleon," alternating between languages to assimilate several of South Africa's overlapping social, ethnic and racial groupings (Noah 2016a: 99).

Noah began his entertainment career in his late teens in his native South Africa by starring in a local soap opera, before moving on to host his own radio show on YFM called 'Noah's Ark" (Mambana 2017). Over the next couple of years, he held many television hosting roles, including his own talk show Tonight with Trevor Noah - based on international shows such as Late Night with Conan O'Brien and satirical fare like The Daily Show with Jon Stewart - before taking to the comedy stage (Nwadigwe 2018). His gradual emergence onto the national comedy circuit saw him performing at local amateur comedy clubs and comedy shows and festivals throughout the country before headlining his first one-man show - "The Daywalker" - in 2009, which sold out large theatres (Nwadigwe 2018). The show also formed the subject of David Paul Meyer's award-winning documentary film You Laugh but It's True (filmed in 2008, and released in 2011), which profiles Noah's early comedic rise in post-apartheid South Africa 
(McCarthy 2017). Noah subsequently went on to write, produce and star in six more widely popular comedy specials, both in South Africa and abroad, including "Crazy Normal" (2011), "That's Racist" (2012), "It's My Culture" (2013), "Trevor Noah: Lost in Translation" (2016), "Afraid of the Dark" (2016) and, most recently, "Son of Patricia" (2018).

After dominating the national stand-up scene in his home country, Noah moved to the United States where he cemented his comedic success by becoming the first South African comedian to crack the US market, performing on The Tonight Show with Jay Leno and The Late Show with David Letterman, in 2012 and 2013, respectively (Mambana 2017). Shortly after, in 2014, the star joined the wildly popular and globally circulated The Daily Show with Jon Stewart as a recurring contributor and correspondent, before ascending to the ranks of global comedy royalty when he was anointed successor to Stewart in 2015 (Bahr 2016). Despite the initial controversy surrounding Noah's appointment on the show, following previous Twitter posts which contained jokes that could be considered offensive to women and Jewish communities, as well as the circulating rumours that he poached material from other stand-up comics, Noah, in his role as host of the show, has gone on to garner a bevy of award nominations (and wins), including snapping up the "Best Host" award at the 2017 MTV Movies and TV Awards, beating out the likes of Ellen DeGeneres, Samantha Bee, John Oliver and RuPaul. While viewership of The Daily Show with Trevor Noah was initially below that of the peak days of Stewart, the show has steadily gained ground in its ratings over the last couple of years, resulting in Comedy Central extending Noah's contract through to 2022 (Bradley 2017). In particular, the show's rising ratings have been driven by increased viewership among younger and more diverse audiences (Bradley 2017). Noah's new-found international success on the show has also led to the release of his first autobiographical book - an instant best-seller - titled Born a Crime: Stories from a South African Childhood (2016), which chronicles his upbringing in South Africa during the tumultuous apartheid era, as well as a second book which he wrote alongside The Daily Show writing staff, titled The Donald J. Trump Presidential Twitter Library - comprising hundreds of Trump tweets. By 2018, Noah had signed a multi-year contract with Viacom, launched an international production and distribution company called Day Zero Productions (Steinberg 2018), and was even named as one of TIME Magazine's 100 Most Influential People of that year.

Noah's comedic sensibilities have been fundamentally shaped by both his challenging upbringing during apartheid and by his complex racial identity, which is as difficult to categorise in his home country as it is in America. The result is a distinctive strain of racially inflected comedy frequently characterised by heavy accents, caricatures and in-jokes, all informed by racial stereotypes and which skirt the boundaries of offence and political correctness. His multilingualism is a rich vein of his comedic material, at least in South Africa, and his ability to mimic the many different dialects in his native country provides him access to a range of audiences across the South African "colour" spectrum: a level of accessibility and relatability that few other comics can match. As a result of his own particular biography - rooted in his marginal subject position as a "mixed-race" minority (in both South Africa and America) Noah seems to be granted a greater degree of comic license regarding racialised discourse relative to other comedians. Neither unequivocally black nor undeniably white nor even "coloured," by his own account (2009), Noah is uniquely poised to broach racial subjects and navigate cultural difference without inviting scorn or scrutiny, or, at the very least, rendering such sensitive subject matter (more) palatable.

\footnotetext{
${ }^{1}$ The term coloured is an official ethnic category in South Africa to describe multiracial citizens made up of the mixed descendants of the British, Dutch, Malay, Indonesian and native Africans (Nwadigwe 2018).
} 


\section{Noah as a South African comedian}

Following the demise of the apartheid state (and its watchful surveillance and censorship), South Africa's comedy scene experienced a mushrooming of comedy venues, comedy festivals and comic talent in the late 1990s (Seirlis 2011: 513; Eddy Cassar Public Relations and Promotions 2017), with comedians even being sought after as corporate entertainers, television presenters and for commercials and advertisements (Seirlis 2011: 513). Post-1994 comedy marked a significant break with the country's socio-political history of extreme limitation and puritanical strictures, with previously marginalised individuals now capitalising on their new-found political freedom, readily reflected in the emergence of a new breed of young non-white comedians such as Tumi Morake, Loyiso Gola, David Kau, Kagiso Lediga and Trevor Noah, amongst others (Snodgrass 2016). Indeed, by the turn of the millennium, these young black comics joined the ranks of a handful of popular white comedians and soon outnumbered their white counterparts. At this time, the mounting number of non-white comic performers was equally reflected in the (racial) diversification of the audience, with comedy events even being targeted exclusively at black audiences, such as the well-known "Blacks Only Show" which began running annually across the country in 2004 (Pampalone 2016).

In addition to amending the racially skewed local comedy stage, this new generation of comics also marked an enormous expansion in youth culture, both amongst comedy audiences and comedians themselves (Seirlis 2011: 517). Comedy in the early 2000s provocatively stretched the limits of what could be laughed at in the post-apartheid era, with comedians increasingly engaging with the broadest social, political and economic conditions confronting the country such as social inequality, crime, the HIV/AIDS epidemic (Seirlis 2011: 521-522), corruption, racism and debunking racial myths, and challenging political correctness with a sense of humour (Snodgrass 2016). Undoubtedly though, race remained (and continues to remain) centre stage for comedians across the country, with social comedy serving as a promising tool in addressing changing cultural standards and negotiating cultural difference in the wake of the nation's transitional and transformational progression towards democracy. Against the backdrop of this thriving comedy scene, Trevor Noah emerged as a breakout star, in particular by way of his first one-man show in 2009, "The Daywalker," which made headway for South African stand-up comedy in a film of the same name, and challenged the acceptable limits of racialised discourse in the new "Rainbow Nation.".

\section{1. "The Daywalker"}

The title of Noah's debut special emanates from the satiric fact that during apartheid he was said to be an albino: a ploy by his family to explain his light skin to the rest of his (black) Soweto Township. Believing Noah to be indeed an albino, his childhood friends humorously assigned him the nickname of "daywalker," alluding to the fact that he could walk around in broad daylight without suffering the sun damage associated with phenotypical albinism. In addition to carrying racial and ethnic connotations, the epithet also evokes the pop cultural trope of the daywalking vampire (which finds its origins in the Marvel Comics' African-American character Blade): a human-vampire hybrid whose abilities outstrip those of both species. In a similar vein, Noah's visible racial ambiguity allows him to manoeuvre through a range of contested and complicated racial discourses and offer scathing social critiques that are otherwise prohibited.

Filmed in Johannesburg and broadcast in South Africa, the two-hour-long (special edition) comedy show draws upon intimate and immediate knowledge and understanding of South

2 "Rainbow Nation" is an epithet that alludes to non-racialism and colour-blindness in post-apartheid South Africa, promoting the image of different racial, ethnic and cultural groups being united and living in harmony. The term was coined by Archbishop Desmond Tutu during the advent of democracy in the country. 
African politics, current events, cultural and geographic references, as well as (South) African languages (as Noah routinely performs and code-switches between various [South] African languages and accents within the same performance). For instance, the opening segment of "The Daywalker" features a number of parodic performances of Jacob Zuma (the President at the time), ${ }^{3}$ not least of which includes Zuma declaring that while Mandela might be the father of the nation, he (Zuma) will be the father of a nation - a pronouncement that Noah delivers in Zuma's stereotypical staccato oratory style. The joke is contextually anchored on a particular South African context, relying, as it does, on prior knowledge of the many controversial matters related to Zuma's sexual prowess and his polygamous lifestyle. However, at the same time, Noah also attempts to link his comedy to a wider global, and in particular American, racial context. Evoking Michael Jackson, Tiger Woods, Venus and Serena Williams, Alicia Keys, Beyoncé and Oprah Winfrey, he contrasts the South African and American experience of race in a manner that highlights the apparent privilege of African Americans with respect to the experiences of those who are simply African, for example, when Oprah Winfrey flies in her private jet to visit her charity schools in South Africa. The constant interplay between the local and international context illuminates the fluidity, complexity and consequences of different racial formation systems, with Noah's lighter than black but darker than white body serving as the site for this exploration. Indeed, throughout the set Noah crafts a distinctive (multi)racial comic persona through his performance of identity, which "shifts" with time, space and place between African, bi-racial, coloured and also black American. In doing so, Noah articulates the vicissitudes of mixed-race identity which speaks to a broader narrative of "outsiderness," racialisation, cultural difference, bodily displacement and misidentification across the special.

\subsubsection{Mixed-race identity in "The Daywalker"}

As the title of the special suggests, much of Noah's performance focuses on his mixed-race identity. This is most readily apparent in the second and third acts which engage with race and its associated dimensions of ethnicity and identity via anecdotal vignettes parcelled into specific experiences with strangers, family, South Africa and America. Lasting almost thirty minutes, the first of these is concerned with Noah's negotiation of his "coloured-ness," but also touches upon the identity politics of the coloured community. This includes a digression about how some accents sound more dangerous than others - explored through a scene of Indian and Russian actors alternately playing the role of a villainous terrorist - and features a virtuoso imitation of stereotypical Cape Coloured, thick East Indian and Russian accents. The section also features observations about the racialisation of employment and the socio-economic inequalities within (and fragmentation of) the once united black racial group, explored through a comic portrayal of the Chinese who, in post-apartheid South Africa, are on a quest to become "black," or as Noah puts it, "brack" (playing on the linguistic stereotype of Asian accents swapping Ls and Rs in English), in order to prosper from the new dispensation, seeking guidance from "master" Jacob Zuma.

The highlight of this second act though is undoubtedly Noah's experience with a comedian, Peter, backstage at a show in London. In Noah's narrative, Peter comments on Noah's "really strange accent," inquiring "where you from?" Upon learning that Noah is from South Africa, Peter readily assumes that he is Zulu (that is, black), and when Noah corrects him by stating that he is in fact coloured, Peter condemns the word as "racist" and "old-school," opting for the supposedly less offensive epithet " $n *$ gger" instead, or better yet, the so-called politically correct

\footnotetext{
${ }^{3}$ In South Africa, Zuma has often been the object of ridicule due to his penchant for singing and dancing during serious political debates, his polygamous lifestyle (he currently has 6 wives and over 20 children) and an unfounded comment he made during his 2006 rape trial that showering after sex would minimise the risk of contracting HIV.
} 
world-wide term for people like Noah - "mixed-race" - insisting that Noah is "free here brother." The punchline of the joke, which highlights the contextual determinants on the meaning of the term "coloured," is premised on Noah's assertion that "Coloured in South Africa is more than just a colour; it's a culture - a group of people." Indeed, contrary to the EuroAmerican usage (where the term is categorically and historically accreted with implications of black oppression and is considered a racial qualifier), in South Africa the term is largely regarded as a cultural qualifier that coincides with a specific, officially sanctioned, (multi)racial identity. As such, it is the term "mixed-race" that would be considered offensive in the South African context, a sentiment that Noah delivers in a stereotypical, over-exaggerated Cape Coloured accent through the following idiolect: "Jou ma se mixed-race." This plays on the derogatory Afrikaans slang "jou ma se poes," which loosely translates to "your mother's c*nt" and is often equated with "fuck you." At this point, stepping out of the moment, Noah further complicates his already somewhat "unstable" identity by informing the audience that he is not "coloured coloured," but rather thinks of himself as a "BEE baby." This concluding remark references the lexicon of the South African economic policy Black Economic Empowerment (BEE): a programme which encourages the business sector to promote the creation of a racially inclusive economic landscape by ensuring black peoples' involvement and co-ownership in businesses. By evoking the BEE policy as a marker of self-identity, Noah seemingly signals a cultural identification with blackness, further destabilising any clear sense of his racial identity, which inevitably highlights the heterogeneity of ethnicity and undercuts the popular assumption that race and ethnicity are codetermined. The sequence thus illustrates the manner in which Noah's comedy calls attention to his body, cites the expectations mapped upon him, experiments with the possibility of these meanings, and then highlights the spaces for negotiation pried open between bodies and bodily discourses.

Nor is the ambiguity regarding Noah's racial and ethnic identity presented as simply a consequence of transnational ignorance. In the same joke series, for instance, Noah recounts an encounter with a coloured man in Cape Town: the city that hosts the largest coloured population in the country. Presuming Noah to be coloured, the man speaks to him in Afrikaans (an assumption premised on the fact that most coloureds speak Afrikaans as their mother tongue). ${ }^{4}$ However, the comedy of the routine is premised on Noah's inability to speak the language, with the exception of a few basic phrases, such as Nee bass, moenie my slaan nie (Afrikaans for "No boss, don't hit me'), which serves as an obvious indictment of apartheid's ruling Afrikaans party which sought to impose a racial hierarchy between the white (Afrikaans) government and the non-white racial groups. Noah thus acts out the awkward dialogue between himself and the coloured character, both of whom seem unable to communicate with each other - from the stranger "speaking so fast" to Noah "thinking so slow" and his "funny" way of speaking leading the coloured man to ask Noah "Where're you from? Are you from overseas?" These questions, which mirror Noah's earlier experience with the British comedian, are reflective of shared experiences of minorities and operates through racism on the basis of a presumed "other," thus embedding a sense of social exclusion from an identity. When Noah informs the gentleman that he (Noah) is in fact from Johannesburg, and, by his own admittance, "just different" referencing his accent, although this linguistic variance speaks to a broader sense of (cultural) difference - the coloured man labels him "one of those banana types: yellow on the outside but white on the inside." The sense of Noah's outside status is even further complicated by his flawless vocal transitions between the performance of his own Standard English and the stylised Afrikaans of the coloured character: a series of transitions that flags the articulation of racial identities through the lens of language. Moreover, beyond signally Noah's dis-identification

\footnotetext{
${ }^{4}$ In addition, most coloured people are bilingual, comfortably codeswitching between Kaapse Afrikaans (a creolised dialect of Afrikaans spoken mostly in Cape Town) and suiwer Afrikaans (formal Afrikaans as used in schools and media), as well as standard South African English.
} 
with his phenotypic-cultural identity - an observation further amplified by his inability to successfully navigate a conversation with the character - the sequence, in conjunction with the previous one, also works to frame Noah as the subject of both local and global oppression, a notion that takes full effect in the next act when Noah travels to America.

\subsubsection{Racial performance in "The Daywalker"}

"The Daywalker's" major narrative arc, which lasts almost 60 minutes, is built around an extended discussion of Noah's upbringing during apartheid, which allows him to touch upon issues of racial violence, cultural difference and socio-economic marginalisation along lines of class and education - which he explores through a sequence on Oprah's school in South Africa. In particular, this third act focuses on Noah's identity crisis as a result of a number of structural, institutional and legal regulations and procedures both during and after apartheid which caused his racial identity to be reclassified three times. Noah explores each of these stages of his life through various humorous anecdotes, from his misidentification as an albino whose hair mysteriously grows out black, to his identity being rectified to that of coloured in 1990 following the demise of apartheid - for which his family throws a celebratory "coming out" party which his uncle humorously mistakes for a gay declaration - to his identification with transnational blackness.

In one of his most insightful sketches in this section, Noah introduces his inner desire to be black through an anecdote about his first trip to the United States where, his family tells him, he will finally "get to be black," as any visibly discernible trace of African ancestry automatically constitutes blackness in America. In this sequence, Noah plays the wide-eyed foreigner, totally oblivious to the racist undertones of this American practice, and it is this naivete that helps call attention to (the absurdity of) such discursive constructions that mark people of colour as outsiders. In the skit, Noah frames black Americans as the epitome of coolness, intimated by his assertion that "everyone wants to be like them; everyone in every township in the world ... yo yo my nigga." He practices performances of American blackness on the entire 18-hour flight over, polishing up on performance cues that signify authentic blackness in the US, adopting moments of slang and African American (vernacular) English, in particular the expression "ya'know I mean." The entire joke leads up to Noah's arrival in the US, at the Miami airport, where he readies his performance of blackness (finally), only to be approached by a man who proceeds to speak to him in Spanish. The punch line is, once again, ironic failure of recognition, yet Noah ups the stakes in this joke by performing a Mexican man with full commitment. As a result of his skin colour (which could easily be read as Latino) and his adoption of a Mexican dialect, Noah presents this misrecognition as understandable, which calls attention to how race is more tied to context, language and performance than biological essence or materiality. Indeed, in this routine and throughout the set, Noah actively plays with the limiting discourses of African-ness, blackness, coloured-ness and whiteness tied to both body and language by embodying and citing these discourses (through the adoption of physical and vocal choices) and then quickly tossing them aside. This embodied ironic play - highlighted by Noah's repeated misidentification - continually works to expose the social construction of race and undermine its essentiality. This performance, then, is indicative of the broader comedy of "The Daywalker," which certainly does not shy away from trafficking in controversial and potentially offensive remarks about, and representations of, race, but at the same time, also demonstrates a deeply informed and sympathetic sense of nuance regarding how race is experienced and expressed. Noah's comedy in "The Daywalker" is intricately tied to his racial hybridity: he is at once an insider (mimicking in ways that register intimacy with the insiders, not mockery) and an outsider (able to turn on the insiders from perspectives that are different and other). It is this double-ness, 
or perhaps even multiplicity, that is crucial to his relative comic license and political efficacy in this comedy special.

\section{Noah on the global stage}

"Son of Patricia" emerges out of a very different moment than Noah's earlier works such as "The Daywalker." Not only has the technological and institutional infrastructure of international comedy changed significantly since 2009, but Noah's own circumstances have dramatically altered. In terms of the institutions of comedy, this period can be characterised by the rise of the Netflix streaming video platform as a key distributor of international comedy. Sweeping aside the dominance of long-time players such as the American cable channels HBO and Comedy Central, Netflix's promise of unparalleled international distribution has led to its rapid rise as an outlet of choice for many international comedians through the increasingly standardised format of the "Netflix Comedy Special," of which "Son of Patricia" is Noah's second entry. In the case of Noah himself, we also need to account for his own change in fortunes during this time. While well known in South Africa in the early 2000s, by 2019 Noah has emerged as a highly influential and successful international comic figure. Central to his newfound reach was his 2015 appointment to The Daily Show, and the 2016 publication of his memoir, which not only helped solidify his role as a significant spokesperson on 21 st century racial politics, but also introduced the figure of his mother, Patricia - whose name provides the title of the 2019 comedy special - to a global audience. By 2019, Noah was therefore more than just a comedian: he was a noted international commentator on questions of race and politics.

This shifting context means that "Son of Patricia" entered into the world subject to an entirely different set of audience expectations and assumptions than had attended Noah's preDaily Show specials. For example, in 2018 Noah faced widely-reported criticism in Australia, and calls to boycott his "Tour Down Under" following revelations of a joke delivered during his "It's My Culture" show in 2013. The punchline of the offending joke suggested that Australian Aboriginals may be the one exception to his claim that "women of every race can be beautiful," which was then compounded by a lewd reference to playing the traditional Aboriginal instrument, the didgeridoo. The routine was found in a YouTube video of the (at the time) sixyear-old set, and was quickly shared through social media platforms where it prompted widespread criticism from leading Aboriginal commentators, which then caught the attention of global news media. Central to many of the passionate objections to Noah's joke were appeals to a wronged sense of solidarity between international "people of colour:" as a non-white comedian of African descent, it was assumed that Noah would exhibit greater sensitivity and awareness regarding the perpetuation of racial prejudice (Hurley 2018). This incident captures the increased international scrutiny that Noah now bears as a result of his global status and the increasing complexity this necessarily brings to his comic treatment of race relations. This situation is only compounded by the transnational reach of the Netflix platform: gone are the days when Noah could perform to a single local or even national audience. The distribution of Netflix content instead ensures the increasing likelihood of a global audience for Netflix comedy specials: a potentially worrying development for comedians given the extent to which humour is often located in specific local cultural contexts (Eco 1987; 269-273; Critchley 2002: 67-68) and the subsequent potential for offence when humour moves outside of its original context (Reimann 2010; Moalla 2015). Indeed, as the Australian incident illustrates, even his historical shows are now subject to a new form of global visibility: retroactively re-experienced as if addressed to a diverse, worldwide audience by virtue of their digital afterlife. In 2019, Noah is thus no longer simply an (South) African comedian; he increasingly operates as a representative of a new form of global(ised) comedy of colour. 


\section{1. "Son of Patricia"}

There was, then, a heavy, complex and just plain complicated set of expectations for "Son of Patricia" to live up to. Although explicitly filmed in Los Angeles, this comedy special is filmed and performed in a manner that suggests that it is very much aware of its global audience: shifting its register between the local and the international, it illustrates the increasing unavoidability of the dual audience of mediated comedy (Goltz 2017: 93-97). Los Angeles thus functions as an appropriate location for what is ultimately a global performance: an American city that is transnational in terms of both its orientation and its profile. Noah's material is also deeply invested in cultivating this sense of a dual local-international outlook by taking up a series of subjects that simultaneously speak to a particular Californian identity and a broader narrative of cultural difference and mistranslation across the special. Thus, although "Son of Patricia" opens with the almost compulsory engagement with the local context - via a pedestrian and startlingly predictable series of observations about traffic conditions - it quickly transitions into a more expansive register anchored in three longer anecdotal segments, all of which are ostensibly based on his personal experiences.

The first of these is concerned with a trip that Noah has taken to the Indonesian island of Bali with some American friends. Lasting roughly twenty minutes, the Bali sequence touches upon questions of cultural authenticity and identity, expectations around masculinity and a comic critique of tourism practices. During this section, Noah highlights his African identity and presents it as a source of solidarity with the local Indonesians, which sets him apart from the shallow voyeurism of other Western tourists. The highpoint of this first act is Noah's account of a "snake show" in which he recounts watching a variety of snake-based performances as part of a tourist showcase. In Noah's narrative, he is ridiculed by a French father and son after he retreats to the back row in fear of the snakes, ${ }^{5}$ only to be vindicated when the starring cobra goes rogue and bites his keeper before lunging into the crowd. Noah is a highly accomplished storyteller, reeling the audience in through the modulation of volume and making use of digressions and repetitions to extend the suspense prior to the snake's final break for venomous freedom.

This opening section then transitions into a bridging sequence concerned with the "history of racism" as explored through the imagined relationship between escaped slaves and abolitionists in the Underground Railroad, which then gives way to Noah's account of a conversation he had with President Barack Obama and an awkward misunderstanding around the distinction between AIDS and aides. This is all preamble, however, for the second major act of the performance, which is built around an extended discussion of Noah's first experience of a taco, which again serves as a means for noting and discussing his exception to American assumptions and experiences. This topic allows him to touch upon a number of subjects, including an outsider's experience of American culture, the failures of "white people's cooking," food truck culture and an extended poo joke premised upon the different meanings of the word "napkin" in American and South African English. The routine ends by taking up President Donald Trump's anti-Mexican comments as the starting premise for a number of fairly unremarkable anti-Trump jokes. The set then closes with a final section addressing Noah's African origins, and how his experiences as a black African shape his encounters with American racism. In particular, Noah dwells on one incident in Chicago, where a man in a passing pickup truck calls him "the N-word." Reflecting on the lessons he learned from his mother, Patricia, Noah recounts how he responded to this abuse with good cheer, before finally launching into a final routine addressing the alternate meaning of the $\mathrm{N}$-word in American and African contexts, premised on his assertion that "that word" was never used to oppress anyone in Africa.

\footnotetext{
${ }^{5}$ In doing so, Noah invokes a widespread belief in South Africa that the black population is afraid of snakes.
} 


\subsubsection{Negotiating privilege in "Son of Patricia"}

The tension evoked by Noah's sustained comic discussion of the N-slur, where he both confronts and transcends one of the central taboos of American racial politics, is indicative of the manner in which the comedy of "Son of Patricia," more broadly, seeks to negotiate Noah's status as a global comedian of colour. In order to do so, Noah constructs a comic persona that is simultaneously globally cosmopolitan and also subject to multiple forms of local oppression. This identity is suffused with tension, not least due to the special's reliance upon comic anecdotes that draw upon Noah's international celebrity lifestyle. This is most immediately apparent in his extended Bali anecdote: while certainly the host to a large number of Chinese and Australian tourists, Indonesia is not a traditional holiday destination for Americans. Indeed, when Noah advises "if you've never been, make a plan and get out there," stifled laughter can be heard in the audience, as some audience members initially respond as if this endorsement were a joke (the abruptness with which the laughter stops potentially even suggests that the audiences' microphones may have been cut in order to limit the reproduction of this response in the special). The evocation of Bali - an incredibly distant and unfamiliar locale for his immediate audience - thus threatens to draw attention to how Noah is not only different from his audience, but also potentially privileged in relation to them: a designation that would in turn threaten his comic persona as an authentic voice of racial oppression. Consequently, it is this sort of identity that Noah must consistently work to counteract throughout the special, by encouraging interpretations that work to shore up, rather than destabilise, his claim to underdog status.

A primary, although somewhat counterintuitive, method by which Noah achieves this end is through the frequent use of comic accents and impersonations. While accents have a long history in comedy as a means to ridicule ethnic or distinct social groups (Mühleisen 2005: 226), in the context of "Son of Patricia," as with "The Daywalker," Noah's use is more politically complex. Most notable and frequent are Noah's American accents, which cannot be reduced to any straightforward function of mockery. Throughout the special, Noah performs a number of racially coded and regionally inflected American accents, but the most prominent during the Bali section is the Californian drawl by which he characterises his travelling companions. During this anecdote, Noah's repeated invocation of the accent works to define his fellow tourists as not only distinct from himself, but also as the bearers of (white) tourist privilege in this location. It is they, the white Californians, who are thus made out to be the intrusive gawkers who are commodifying this foreign culture, which then leaves Noah free to claim a form of transnational solidarity with the Balinese locals. Noah thus uses a comic accent to reaffirm his claim to an underdog status, by distancing himself from a group that he positions as dominant. This comic act of misidentification is deeply unstable though: just because Noah is not one of the "Americans," does not mean that he is therefore the ally of all exploited peoples, as is made apparent in Noah's brief attempt to impersonate a Balinese accent. Although he begins in full flourish, with clipped syllables and a singsong intonation, the accent very quickly fades away. Indeed, by the middle of the third sentence Noah speaks with his regular voice, even as he continues to play the part of a local tour guide. Moreover, although multiple Indonesian characters appear throughout this sequence, Noah's attempted Balinese accent never returns in full-force. To all appearances, in mid-performance, Noah realises the unequal racial relations and history of racial caricature that such an imitation almost invariably invokes, and pulls back from his impersonation. ${ }^{6}$

\footnotetext{
${ }^{6}$ The same cannot be said for Noah's repeated French accents during the snake performance routine which are excessive to the point of Pepe le Pew-inspired pantomime. In their excess, however, they evoke a long history of continental comic foils in both the American and English traditions. As a result of that long tradition, there is little sense that Noah is launching an unwarranted or harmful attack upon French people and their culture;
} 


\subsubsection{African identity in "Son of Patricia"}

In contrast, Noah's navigation of racial politics is more consistent, and arguably more successful, when expressed in terms of his specific African identity, which he invokes as a means to de-familiarise established patterns of American racial politics. In "Son of Patricia," Noah can no longer make a claim for the highly complex and dynamic identity that characterises his performance in "The Daywalker," nor the comic vantage point that his identity affords. Whereas in South Africa he plays with his multiple racial identities, in the America context, he is categorically black. As such, he purposefully asserts his African identity as a way to position himself as an "outsider" - a foreigner supposedly ignorant of American racial politics - which allows him to launch comic critiques at myopic American attitudes towards race, with a measure of forgiveability. It is this sense of identity that is at the heart of Noah's repeated engagement with the N-word, and which forms the basis of the special's final sequence. However, while both the comic and political payoff of Noah's evocation of the N-word only occur in the closing minutes, the setup for this critical punchline is laid throughout the routine, as he alternately dodges the word and then leans into it. This is most apparent in a short riff on the origin of the term " $n *$ gger, please" during the history of racism sequence, which concludes with Noah using that phrase seven times in thirty seconds: seemingly daring the audience to object to his enthusiastic repetition.

Throughout the routine, then, Noah shifts between serious, glib and increasingly gratuitous engagements with, and evocations of, the $\mathrm{N}$-word, and thereby lays the groundwork for his final sequence during which he again repeats the word seven times in quick succession, before reflecting on how uncomfortable this makes his American audience. This discomfort, he makes clear though, is in service of a larger point regarding how racial taboos shift between contexts, as he asserts that the word "was never used to oppress" anyone in Africa, and therefore has no power there. In a comic but pointed condemnation of the imperialist expansion of American racial politics, Noah thus concludes the special by noting that in his mother's Xhosa language, the word means "to give," and therefore, for him, the word evokes "fond memories of his childhood." This final joke is about more than language though: it functions to acknowledge, but also undercut, the power of the $\mathrm{N}$-word in a manner that speaks to a rejection of the narrow scope of American race politics in favour of a broader awareness of the complex global circulation of race. Noah's phonetic parallel de-familiarises the most taboo of American racial epithets, and thereby undercuts the otherwise assumed hegemony of America's particular linguistic anxieties around race and racism.

In these closing moments, Noah thus asserts his "African" identity in service of a more global position, one that is pointedly outside of, and not bound by, the racial politics of the particular America context: the comic manifestation of an incipient global racial politics whose horizon is not bound by the racial histories and struggles of the USA.

\section{Shifting contexts of racial comedy}

The comedy of both specials is tightly bound up with questions of race and racism; however, the manner in which those topics are presented as a legitimate subject of humour differs meaningfully between the two performances. Produced and circulated in distinct social contexts shaped by fundamentally different histories of racial politics and racial-political anxieties, their comic treatments of race reflect not just different sensitivities and assumptions around race in South Africa and the USA (Goldberg 2009: 67), but also provide differing examples of the

instead, the impression is of a riff upon a venerable, perhaps clichéd, comic tradition. Consider this in comparison to the affront expressed by the Australian aboriginal community. 
political function that racially-concerned comedy can serve. In neither instance can Noah's comedy be entirely accounted for in terms of the dominant state formations of race, but the influence of those formations is certainly present in the ways he jokes about race. Thus, while Noah's comedy remains consistently concerned with topics such as the navigation of racial boundaries, the critical potential of outsider identities, and the sanctity of social taboos around race, the particular ways in which he addresses those subjects across the two specials illuminates how the potential politics of comedy and race can shift between those different contexts. Attending to the differences and similarities between the two specials thus provides a way to map out the contingent dynamics of the politics of racial comedy and the potential interventions that it is capable of making. The differences between the two specials is therefore instructive not only in terms of the arc of Noah's career and comedy, but also in making sense of how the comedy of race can do different political work in different social contexts.

At the most immediate level, there are clear formal points of difference between the two specials: "The Daywalker," for example, is unusually long for a comedy special. Clocking in at just over two hours, it is almost twice the length of "Son of Patricia." As may not be surprising given its earlier production, "The Daywalker" is also less technically polished: the camera work is relatively static, Noah uses an older cable microphone, and both he and his audience are darkly lit. While not necessarily definitive, such variations in presentation have the potential to exert an influence on how the performance is interpreted, especially by the non-immediate audience. In contrast, Noah's style of comic presentation remains remarkably consistent between the two specials: by the time of "The Daywalker," the central aspects of his stand-up act - including impersonations, observational humour and the occasional absurdist storytelling, all executed in a chatty charismatic manner - are already in place largely as they will appear in "Son of Patricia." Although there is slightly more vulgar content and language in the earlier special, his "polite" manner of delivery is also nonetheless largely in place. Between the two specials, then, there are only minor differences in Noah's tone and style, which are mainly cosmetic, rather than expressing a significant shift in his comic performance. Substantial differences between the racial comedy of the two sets are therefore best understood in terms of the shifting sensitivities and structures of comic feeling in which they are located, rather than being indicative of any substantial shift in Noah's comic style or performance.

\subsection{Comic identity in transition}

One of the major sites at which this difference manifests itself is through Noah's treatment of the status of racial identities and boundaries. Indeed, much of the comedy of "The Daywalker" arises out of a play with the fluidity and slipperiness of racial identification that Noah experiences in South Africa: the incongruity between his own illegible (indeed illegal) racial identity and the categories made available to him by the state. In doing so, he slips between different regimes of racism and demonstrates how the "racial absolutisation" that informed the Apartheid state continues to persist in the ostensibly raceless social order of the "Rainbow Nation" (Goldberg 2009: 311-321). Simultaneously trickster and fool, Noah actively plays with this incongruity when he adopts the identity of the day-walking albino and self-consciously styles himself as African American. To comic effect, he resists and rejects attempts to firmly locate his identity by interlocutors, such as Peter the British stand-up comedian, and instead uses his own facility with code switching to ridicule and mock those who would attempt to pin him down. However, Noah is not always so successful in his attempts at self-determination, most obviously at the US border when his younger self's embrace of racial ambiguity backfires, and he is interpellated as Latino in spite of his active cultivation of an African-American identity. In that instance, he becomes the butt of his own joke, which is only heightened by his prior hubris. 
It is perhaps not surprising, however, that it is in the USA that Noah's comic play with race is thwarted. This outcome foreshadows how his racial humour shifts in "Son of Patricia" where a different set of racial norms makes it more difficult to locate comedy in racial transition and transgression. Though Noah certainly continues to shift between multiple identities in the second special, assisted through his facility with accents and impersonations, there is less of a sense that he is performing his own fluidity than mapping out a number of different ethnically distinct sites. Indeed, Noah - the accent-shifting, identity-fluid, racial chameleon - is no longer as central to the humour: instead, we have an increased focus on conversations with, and even between, racially stable subjects (with Noah playing both sides). Such an approach is conversant with the racial order of the American state which adopts "homogenised apartness [...] as the deracialised norm" (Goldberg 2009: 92), and which Noah thwarts through this comic staging of interracial encounters. Thus, in "Son of Patricia," comic misunderstanding is no longer a result of racial ambiguity, but instead, more often, a consequence of gaps in translation between distinct groups: Indonesians and white tourists, white abolitionists and freed black slaves, Noah and a Mexican-American Californian. Indeed, in contrast to the humour of "The Daywalker," that of "Son of Patricia" is premised less on his personal trickster's confusion and more on a structural comedy of racial-ethnic errors.

Nor is Noah himself exempt from this solidification of racial-comic boundaries. Whereas in "The Daywalker" Noah's ethnic, racial and cultural identity is highly complex, in "Son of Patricia" the critical bite of Noah's humour is frequently predicated on his assertion of his African identity. No longer able to evoke the complex racial dynamics of South Africa when performing for an audience that is American first, and global second, Noah instead explicitly claims the reductive identity of "African:" the stark simplicity of which belies the complex manifestation of race and belonging that informs the comedy of the earlier special. What is consistent, though, is Noah's self-positioning as an outsider and an exception to the racial structures of his context. In "The Daywalker," this takes the form of a comic assertion of his own racial uniqueness as a platform from which to launch comic critiques against almost all racial categories. In this performance, any racial or ethnic group appears as fair game for his mockery as he enacts forms of racial caricature that would be unthinkable in a US context: for example, the impersonation of a Chinese accent, the parodying of African-American celebrities as ignorant, and the repeated comic interrogation of the failures of black Africans, most notably prominent politicians. In stark contrast, in "Son of Patricia," Noah mobilises his African identity as a way to signal his exception from the largely binary structures of US racial discourse. In doing so, he gestures towards the possibility of a racial politics that exists beyond the sharp boundaries and ethical outrage that so often drive American conversations around race, and the possibility of transnational solidarity between oppressed groups: he suggests the possibility of multiple distinct configurations of racism (Goldberg 2009: 66). No longer are Indonesians, or African-Americans, or Mexicans, simply ethnic groups to be ridiculed; they are instead potential allies in the face of larger structures of race-based oppression. Thus, although Noah still offers impersonations of those groups, they are no longer so obviously based in mockery and ridicule: while the use of comic accents might still evoke concerns around comic stereotyping, they are no longer presented as such palpable instances of humour.

\subsection{From comedy of race to comedy of racism}

What we can see here, then, is a shift from a performance premised on the comic interrogation of race and identity, to one that is more concerned with the systems of thought that give rise to such categories. The comedy of "The Daywalker" draws attention to race, race relations and racism across the length and breadth of South African society through a "no holds barred" approach that generates humour through the tendentious breach of racial taboos. The Noah of 
"The Daywalker" does not explicitly decry or oppose racism. He plays with it, even displays it, lashing out in all directions with little apparent concern for racial hierarchies or oppression. Everyone is seen to have a race, and everyone is a fool because of it. Premised upon racial impersonation and denigration, Noah's comedy in this special sits very uneasily with American anxieties around race and identity. In comparison, the Noah of "Son of Patricia" seems to have developed a sense of taboos conversant with the American racial context. No longer is race a set category of identities to be taken on and off, but instead a structural means by which nonwhite groups have been systematically oppressed, and for which Trump stands as the epitome. The experience of race in this sense is what connects Noah, the African, with his Indonesian host, who, he suggests, share a common experience of white ignorance and privilege (which then becomes the subject of ridicule). Thus, rather than a skilful performer of racial difference, Noah's comedy instead rests on his role as a comic advocate of transnational solidarity. Contrary to the intentional and explicitly insensitive treatment of race that characterised Noah's earlier comic mockery of Australian Aborigines, the forms of racial humour on display in "Son of Patricia" align more directly with the racial anxieties of American ideas of race.

This does not mean, however, that "Son of Patricia" is without any potentially controversial material: as in "The Daywalker," Noah does not shy away from racially taboo terms of abuse such as kaffir and $n^{*}$ gger. Indeed, if anything, in "Son of Patricia" he uses them more explicitly, directly addressing the audience's discomfort with the latter term as the basis for a joke. However, the telling difference is that in the later special, Noah takes up the term as the basis for an exploration of the nature of such taboos. The care and craft of this joke is indicative of the wider racial comedy of "Son of Patricia," which is more considered and careful in its engagement with race. Whereas "The Daywalker" embraces an almost anarchic comedy that jokes about race as a means to assert the experience and existence of racial difference, "Son of Patricia" is more concerned with the social and cultural frameworks that give rise to racial thought: if the former is concerned with mapping the differences between black, white, coloured and other racial subjects, then the latter is concerned with mapping how different systems of racial thought produce those differences, and the resulting anxieties and conflicts, in the first place. From "The Daywalker" to "Son of Patricia," Noah moves from a comedy of race to one of racism: from joking about how race shapes the experiences of individuals as part of a nihilistic all against all, to an engagement with how larger ideas of race travel and circulate. As a consequence, Noah's shifting comic emphasis is indicative of how the politics of racial joking are neither singular nor emancipatory in any straightforward way.

\section{Conclusion}

Writing in the New York Times in 2016, Noah called for a comedy that would build communities, rather than eviscerate enemies. He wrote that "[i]n South Africa, comedy brings us together. In America, it pulls us apart" (Noah 2016b). This characterisation is difficult to reconcile with the South African comedy on display in Noah's "The Daywalker," which ridicules and pillories multiple racial groups, most of which have been oppressed many times over. Although tied to an explicit reference to his South African origins, in substance his plea seems closer aligned to the priorities of his new global persona. While it is certainly true that "The Daywalker" is more complex than the "us versus them" that Noah decries in the above piece (2016b), it is difficult to interpret it as indicative of a new form of (discernibly) racially enlightened humour. This complexity is symptomatic of how Noah's comedic success is inextricably linked to his biracial and bicultural "otherness," an aspect of his identity which he invokes throughout both specials in order to poke fun at groups across the South African and American racial and ethnic spectrum. Indeed, Noah's strategic self-location of his racial hybridity (and his foreignness, in the case of 
"Son of Patricia") provides a "safe space" where his socio-political critique can flirt with potentially offensive material but cannot be easily condemned as racist, discriminatory or defamatory by virtue of his multi-layered racial and ethnic background. While it is certainly the case that Noah's specials offer an acerbic critique of South African and American culture that is both instructive and entertaining, providing insightful perspectives of race-relations and cultural acceptance as major factors in the complexities confronting the Rainbow Nation concept of South Africa, and post-civil rights America, it is less clear as to whether such racial joking can be considered to enact a singular politics: either liberatory or oppressive.

In "The Daywalker," Noah's comedy walks a fine line between perpetuating versus undermining racial stereotypes and racism, as he routinely adopts, and shifts between, different racial identities and the assumptions, accents and worn-out tropes that accompany them. This technique, while offering a space to discuss and possibly challenge stereotypes about race and culture, is by no means safe for the comedian or the audience, imbued, as it is, with the dangerous, constant possibility of legitimising racist thoughts and discourse (Goltz 2017: 53 84). Indeed, the extent to which Noah plays with racial denigration and apparently un-ironic stereotyping would be untenable in a contemporary American context, or at the very least, difficult to reconcile with any liberal politics of humour premised in tolerance and respect. There is little concern in the special with differentiating between punching up or down; instead, there is only punching. Comedy is enacted here as a form of anarchic critique that recognises race and all its depredations, but does so almost gleefully. In particular, this is comedy born of the South African context where race cannot be politely excused and certainly not ignored. There is certainly a politics here, then, but not one that seeks solutions or builds communities. Rather, it is a comedy that speaks of a way of living with racism, rather than overcoming it: a premise that aligns with dominant racial paradigms in South Africa, but would not sit easily with a liberal American audience. Consequently, any liberatory politics that might be ascribed to "The Daywalker" need to be understood in relation to the South African context, rather than as indicative of any fundamental property of its comedy.

There is, likewise, a particular politics of race and comedy at play in "Son of Patricia," but it is one that is redolent of a very different political environment and set of political assumptions and taboos. In the later special, Noah's engagement with race is less playful and more respectful. His racial comedy is more moderate and qualified. While he does still broach racial taboos, such as the $\mathrm{N}$-word, he does so in a manner that is tightly regulated by the structure of the performance and explicitly recuperated in conclusion in order to offer comment on the damaging experience of racism. Nor does Noah any longer play at being outside of regular forms of racial classification. Instead, he purposefully adopts an African identity, which he uses as the basis of calls for transnational solidarity. This is, then, a different form of comic politics from that which informs "The Daywalker," one that brooks much less ambiguity and is much more explicit when delineating the ethical and political stakes of racial joking. Relative to the prior special, there is very little consideration given in "Son of Patricia" to the idea that race itself could be a comic category: instead, it is racists and racism, not racialised subjects, that emerge here as the butts of Noah's jokes: a form of humour that aligns with the priorities of contemporary American racial discourse. That is to say, Noah's comic engagement with race is far from straightforward or consistent between the two texts that we have explored. His style of racial comedy is not stable, but is rather a product of both his highly complex (and fluid) identity, and the shifting limits of acceptable racial discourse within the two contexts. There is thus a clear move away from a comedy of race in "The Daywalker" - premised on poking fun at racial identities and categories with unprecedented candour - to a meta-racial comedy about issues of racism and racists in "Son of Patricia."

However, to say that both specials enact a form of politics through their comedy is not to claim for them straightforward political efficacy. As has been made clear in the preceding 
discussion, the politics of both examples is tightly bound up with the context of their production and circulation. Viewed in different contexts, the racial politics of either special threatens to tend towards illegibility and even offence. While there may be a temptation to argue that joking about race can work to challenge and unsettle existing regimes of racial and racist thought, the shifting form of Noah's comedy are also indicative of how racial humour (at least in its most mainstream iterations) can adapt to the shifting paradigms in which it circulates. In both South African and American contexts, Noah's joking about race reflects the wider priorities of the entertainment industry towards profit and the cultivation of viewership, rather than the radical challenge of racial ideologies. Instead, in both instances Noah's comedy plays around the edges of acceptable racial discourse in ways that do not threaten to radically challenge existing attitudes. This does not, however, mean that Noah's racial humour should be considered apolitical: as has been discussed at length, his comic performances are predicated on the politically charged engagement with racism through comedy. Rather, the point is that the racial politics of his comedy shift depending upon their context of circulation. The comparative analysis of "The Daywalker" and "Son of Patricia" thus demonstrates that rather than drawing a clear line between light entertainment and politically meaningful humour, the political valence of racial comedy is best understood as contingent upon wider discourses of race that circulate in national-cultural contexts.

\section{References}

Bahr, J. (7 August 2016). 'Race observations backbone of comedian Trevor Noah's live show'. The West Australian. Retrieved February 2, 2019 from: https://thewest.com.au/entertainment/art/race-observations-backbone-of-comedian-trevornoahs-live-show-ng-ya-113568

Bradley, L. (14 September 2017). 'Trevor Noah will host The Daily Show through 2022'. Vanity Fair. Retrieved June 6, 2019 from: https://www.vanityfair.com/hollywood/2017/09/trevornoah-daily-show-renewed-through-2022

Cohen, A. (2016). 'Voter ID laws disenfranchise minority and poor voters', in Armstrong, S. (ed.), Voter Fraud, Farmington Hills, Michigan: Greenhaven Publishing, pp. 45-51.

Critchley, S. (2002). On Humour. New York: Routledge.

Davis, J. M. (2014). 'Genres and styles of comedy', in Attardo, S. (ed.), Encyclopaedia of Humour Studies, Thousand Oaks, CA: Sage, pp. 455-461.

Donian, J. (2019). Taking Comedy Seriously: Stand-Up's Dissident Potential in Mass Culture. Lanham: Lexington.

Eco, U. (1987). Travels in Hyperreality. London: Picador.

Eddy Cassar Public Relations and Promotions. (2017). 'Jive Cape Town Funny Festival'. Retrieved April 12, 2019 from: http://eddycassar.co.za/jive-cape-town-funny-festival/

Franchi, V. (2003). 'The racialisation of affirmative action in organisational discourses: A case study of symbolic racism in post-apartheid South Africa'. International Journal of Intercultural Relations 27, pp. 157-187.

Fredrickson, G. M. (1997). The Comparative Imagination: On the History of Racism, Nationalism, and Social Movements. Berkeley: University of California Press.

Gillborn, D. (2005). 'Education policy as an act of white supremacy: Whiteness, critical race theory and education reform'. Journal of Education Policy 20, pp. 485-505.

Goldberg, D. T. (2002). The Racial State. Malden and Oxford: Blackwell.

Goldberg, D. T. (2009). The Threat of Race: Reflections on Racial Neoliberalism. Malden: Wiley-Blackwell. 
Goltz, D. B. (2017). Comic Performativities: Identity, Internet Outrage and the Aesthetics of Communication. London and New York: Routledge.

Holm, N. (2017). Humour as Politics. London: Palgrave Macmillan.

Hurley, A. (2018). 'Of mice and meh'. Witness Performance. Retrieved March 24, 2019 from: https://witnessperformance.com/of-mice-and-meh/

Lewis, P. (1989). Comic Effects: Interdisciplinary Approaches to Humour in Literature. Albany, NY: State University of New York Press.

Lockyer, S. \& Pickering M. (2009). 'Introduction: The ethics and aesthetics of humour and comedy', in Lockyer S. \& Pickering, M. (eds.), Beyond a Joke, London: Palgrave Macmillan, pp. 1-26.

Mambana, D. (5 September 2017). 'The rise and rise of Trevor Noah and why we are so proud of him'. The Huffington Post. Retrieved February 2, 2019 from: http://www.huffingtonpost.co.za/2017/05/09/the-rise-and-rise-of-trevor-noah-and-whywe-are-so-proud-of-him a $22077196 /$

McCarthy, S. L. (2017). 'You Laugh but it's True' reveals Trevor Noah as ambitious 25-yearold comedy rookie'. Decider. Retrieved March 3, 2019 from: https://decider.com/2017/03/25/you-laugh-but-its-true-trevor-noah-netflix/

Moalla, A. (2015) 'Intercultural strategies to co-construct and interpret humor'. International Journal of Applied Linguistics 25, pp. 366-385. doi: 10.1111/ijal.12074.

Mühleisen, S. (2005). 'What makes an accent funny and why?', in Reichl, S. \& Stein, M. (eds.), Cheeky Fictions: Laughter and the Postcolonial, Amsterdam and New York: Rodopi, pp. 225-246.

Noah, T. (2009). The Daywalker. Directed by Kyle Ambrose and Delon Bakker. Johannesburg, South Africa: Mannequin Pictures.

Noah, T. (2016a). Born a Crime: Stories from a South African Childhood. New York: Spiegel \& Grau.

Noah, T. (2016b). 'Let's not be divided. Divided people are easier to rule'. The New York Times. Retrieved October 11, 2019 from https://www.nytimes.com/2016/12/05/opinion/trevornoah-lets-not-be-divided-divided-people-are-easier-to-rule.html

Noah, T. (2018). Son of Patricia. Directed by David Paul Meyer. Los Gatos, CA: Netflix.

Nwadigwe, L. (2018). 'Trevor Noah girlfriend, mother, father, brother, family, networth, gay' Buzz South Africa. Retrieved May 4, 2019 from: https://buzzsouthafrica.com/unravellingthe-enigma-that-is-trevor-noah-and-his-replacement-of-jon-stewart/

Palmer, J. (1987). The Logic of the Absurd. London: BFI.

Pampalone, T. (2016). 'The funny thing about race in South Africa'. U.S. News \& World Report. Retrieved February 3, 2019 from: https://www.usnews.com/news/bestcountries/articles/2016-04-06/the-funny-thing-about-race-in-south-africa

Rabaka, R. (2007). 'The souls of white folk: W.E.B. Du Bois's Critique of white supremacy and contributions to critical white studies'. Journal of African American Studies 11, pp. 1-15.

Reimann, A. (2010). 'Intercultural communication and the essence of humour'. Journal of the Faculty of International Studies 29 (1), pp. 23-34.

Perea, J. F. (1997). 'The black/white binary paradigm of race: The 'normal science' of American racial thought'. California Law Review 85 (5), pp. 1213-1258.

Rossing, J. P. (2016) 'Emancipatory racial humour as critical public pedagogy: Subverting hegemonic racism'. Communication, Culture \& Critique 9, pp. 614-632.

Seirlis, J. K. (2011). 'Laughing all the way to freedom? Contemporary stand-up comedy and democracy in South Africa'. Humour: International Journal of Humour Research 24 (4), pp. 513-530. 
Smith, D. (4 January 2013). 'South Africa's new comedians find a nation eager for laughs'. The Guardian. $\quad$ Retrieved April $\quad 2019$ from: http://www.theguardian.com/world/2013/jan/04/south-africa-new-breed-comedians

Snodgrass, L. (2016). 'The Trevor Noah phenomenon: young, black South Africans are standing up'. The Conversation. Retrieved April 4, 2019 from: https://theconversation.com/thetrevor-noah-phenomenon-young-black-south-africans-are-standing-up-53070

Sonn, C. (2006). 'Multiple belongings? Reflecting on the challenges of reconstructing apartheidimposed identities in Australia after immigration', in Stevens, G., Franchi, V. \& Swart T. (eds.), A Race Against Time: Psychology and Challenges to Deracialisation in South Africa, Epping: ABC Press, pp. 335-348.

Steinberg, B. (26 March 2018). 'Viacom strikes content deal with Trevor Noah's Day Zero Productions'. Variety. Retrieved June 5, 2019 from: https://variety.com/2018/tv/news/viacom-trevor-noah-day-zero-deal-1202736236/

Stevens, G. \& Lockhat R. (1997). 'Coca-Cola kids: Reflections on black adolescent identity development in post-apartheid South Africa'. South African Journal of Psychology 27, pp. 250-255.

Sue, D. W. (2015). Race Talk and the Conspiracy of Silence: Understanding and Facilitating Difficult Dialogues on Race. Hoboken, NJ: John Wiley \& Sons.

Trawalter, S. \& Richeson, J. A. (2008). 'Let's talk about race, baby! When whites' and blacks' interracial contact experiences diverge'. Journal of Experimental Social Psychology 44 (4), pp. 1214-1217. 